This is the accepted manuscript of the article, which has been published in

Contemporary Politics. https://doi.org/10.1080/13569775.2019.1663394

\title{
Navigating Coercion in Political Rhetoric: Shifting Strategies to Cope with Intervention by the Troika in Portugal
}

\section{Laia Pi Ferrer ${ }^{\text {a* }}$ and Hanna Rautajoki ${ }^{\text {a }}$}

${ }^{a}$ Faculty of Social Sciences, Tampere University, Tampere, Finland

Laia Pi Ferrer: Tampere University, Faculty of Social Sciences, Kalevantie 4, FI-33014, 33100 Tampere, Finland.

Phone: +358 503187496

e-mail: laia.piferrer@tuni.fi

Hanna Rautajoki: Tampere University, Faculty of Social Sciences, Kalevantie 4, FI33014, 33100 Tampere, Finland.

Phone: +358 503186198

e-mail: hanna.rautajoki@tuni.fi

*Corresponding author: Laia Pi Ferrer; e-mail : laia.piferrer@tuni.fi

\section{ORCID:}

Laia Pi Ferrer https://orcid.org/0000-0001-8655-591X

This is an Accepted Manuscript of an article published by Taylor \& Francis in Contemporary Politics on 11 September 2019, available online: https://www.tandfonline.com/doi/full/10.1080/13569775.2019.1663394

The full reference of the Version of Record (publisher's version): Pi Ferrer, L., Rautajoki, H. (2019). Navigating coercion in political rhetoric: shifting strategies to cope with intervention by the Troika in Portugal. Contemporary Politics, doi.org/10.1080/13569775.2019.1663394 


\section{Acknowledgements:}

We are grateful to Pertti Alasuutari, Leena Tervonen-Gonçalves, members of the Tampere Research Group for Cultural and Political Sociology, and participants of the PhD seminar in sociology at the Tampere University, who gave us valuable feedback on the manuscript.

\section{Disclosure statement:}

The authors declared no potential conflicts of interest with respect to the research, authorship, and/or publication of this article.

\section{Funding:}

This work was made possible by financial support from the Academy of Finland research project “Epistemic governance in policymaking” (grant number 276076, Pertti Alasuutari PI) and Academy of Finland research project "European Solidarities in Turmoil” (grant number 318008, Hanna Rautajoki PI) whose assistance is appreciated. 


\title{
Navigating Coercion in Political Rhetoric: Shifting Strategies to Cope with Intervention by the Troika in Portugal
}

\author{
This article examines how government actors of a nation-state cope with coercion \\ exerted on them by an external source and how they evolve justifications and \\ persuasive arguments when debating and reporting new policies in a setting that \\ threatens to compromise national sovereignty and integrity. We approach the \\ question by analysing two diverse political arenas: parliamentary debates and \\ public accounts by political leaders in the media during the intervention by the \\ Troika in Portugal. The study evidences a variation in strategies to manage \\ coercion: the politicians use both depoliticization and relativization. While \\ discourses of depoliticization are frequent in media, in parliamentary debates the \\ predominant strategy is to emphasize the aspect of agency by relativizing the \\ power of the Troika. Both strategies serve to portray responsibility in the face of \\ external intervention, but in different discursive environments political actors use \\ different rhetorical tools to work on their institutional appearance and legitimacy.
}

Keywords: coercion, political discourses, epistemic governance, legitimacy, Troika, Portugal

\section{Introduction}

The global financial crisis that erupted in the USA in 2007 has caused enormous economic and social problems in many countries, with a particularly negative impact on several European countries. Southern Europe has been especially affected by the economic crisis to the point of requiring international assistance to confront market pressures over their fiscal deficit and debts (Gorjão, 2012). The international bailouts were provided by the Troika, composed of the European Central Bank (ECB), European Commission (EC) and the International Monetary Fund (IMF). The bailouts were agreed between the debtor government and the creditors (ECB, EC, IMF) through a process of bargaining on conditions and negotiations that ended up with an agreementthat is the signature of the Memorandum of Understanding (MoU), which explicitly 
detailed the reforms that should be implemented (Armingeon and Baccaro, 2012). This international involvement in the national policy-making of some European Union Member States has exerted an anomalous influence over national policies' content and it has impaired their autonomy (Armingeon and Baccaro, 2012; Streeck, 2014).

The intervention by the Troika has cast doubts on the legitimacy of the democratic process in the nation-states audited (see Armingeon and Baccaro, 2012; Culpepper, 2014; Sacchi, 2015). For instance, Streeck (2014) has argued that these states have seen their condition reduced to 'democracies without choice’. Matthijs (2017) has argued that the Euro Member States that have suffered the most from the crisis have also experienced a substantial deterioration in the strength of their democratic institutions, as they were forced to choose 'integration' at the expense of both 'democracy’ and 'sovereignty'. In some cases, national governments have implemented reforms against their will in return for bail-out loans (Featherstone, 2015; Gorjão, 2012). Hence, the Troika is perceived as exerting a direct control over the Member States bailed out - that is exerting coercive power (see Carstensen and Schmidt, 2017). Although the requirements established in the MoU are forceful and compelling, they must be submitted to acceptance in the parliamentary organ, which means that they must be tackled discursively by those holding national political power. Therefore, even if they are constrained by the Troika, national decision-makers still have agency in the procedure and the ultimate control of how to implement new reforms. In this paper our aim is to ascertain how government actors of a nation-state cope with coercion exerted on them by an external source and how they evolve justifications and persuasive arguments when debating and reporting new policies in a setting that threatens to compromise national sovereignty and integrity. 
Earlier research has shown how a coercive context actives the tendency of depoliticization in justifications in national politics - that is the denial of the political character of decision-making (Standring, 2018). Therefore, decision-makers play down their room to manoeuvre, which was restricted but nevertheless existent, and thus overstating the constraints imposed on them by the Troika (Gago and Moury, 2017). National decision-makers may justify their decisions by means of various depoliticized discourses. For instance, by claiming that 'there is no alternative' (TINA) (Borriello, 2017; Séville, 2017), arguing that we are in a ‘state of exception’ (Fonseca and Ferreira, 2015, 2016), invoking the ‘necessity and urgency’ conditions (Standring, 2018) or even by ‘shifting blame’ onto international actors (Schmidt, 2007; Traber, Schoonvelde, Schumacher, Dahiya, \& de Vries, 2016). These tactics can be used to show the outspoken unequivocal absence of choice and agency (Watson and Hay, 2003), or then the acknowledgement of alternatives, but only to warn against them as the capacity to act is limited (De Ville and Orbie, 2014). This has contributed to what some authors have claimed to cause the executives to centralize power in order to advance the proposed reforms, some of them 'going beyond the Troika' (Moury and Standring, 2017). At the same time, these tactics help government politicians to evade responsibility for making these decisions and for their consequences (Flinders and Buller, 2006).

In this study, we report an empirical analysis of two political environments and relate our findings to those of prior research in order to examine how common and straightforward the use of depoliticization actually is in political rhetoric dealing with coercion. We will compare politicians' talk in the parliamentary context to their statements in press conferences and similar media contexts during the intervention by the Troika in Portugal. The objective of our study is therefore not to evaluate the impact 
of the Troika on Portuguese policy-making, nor whether and how well they implement the loan programme (see Hardiman, Spanou, Araújo, \& MacCarthaigh, 2019). Rather, we analyse the actual national political discourses to identify the rhetorical strategies by which government politicians justify their arguments and decisions on the Troika's mandate in two different political arenas.

\section{Domestication of Coercion According to the Theory of Epistemic Governance}

Our analysis of the rhetoric used by government politicians in managing intervention in Portugal by the Troika, continues and extends the research on how and in what ways impositions from international organizations (IOs) are used and justified in national contexts. However, it is important to note that the Troika is a particular type of international organization making recommendations. Its intervention is embedded in the organizational framework of the European Union and is intertwined with its membership obligations and imbalances. Given the pressure of unresolved economic crisis, Troika has been even further authorized by the Member State in question to take an enhanced role in terms of the hierarchy in command. Thus, the measures that the intervention imposes are binding obligations, a condition for providing financial support, where the nation has itself taken the initiative. Yet, at the level of political processes, the aspect of external coercion compromises national sovereignty and integrity. The setting exposes the deficiency and incompetence of the state to survive on its own through economic crisis, which puts the national representatives severely on the defensive in regard to justifications.

Two theoretical concepts are at the centre of our research: domestication and epistemic governance. Domestication is used to conceptualize the process generated when a new element is introduced into new terrain (see Haddon, 2007). In the case of 
politics, domestication implies the actual process and practices through which international or exogenous ideas and elements infiltrate national spheres, thereby affecting domestic policies (Rautalin, 2013). In this study, the Troika and its impositions were the new elements in Portuguese policy-making, and thus they challenged the existing routine and practice within the nation-state. In such a situation, politicians take and adapt the binding ideas to the nation, incorporating the impositions as part of daily politics and as natural and self-evident elements to take into account when justifying their claims (Alasuutari and Qadir, 2013).

In their efforts to domesticate coercion, politicians naturalize it and incorporate it into local practices with the help of epistemic governance - that is, with the help of the political rhetoric to persuade their peers and the citizens of what the current situation of the nation is and what reforms are to be made (Alasuutari and Qadir, 2014). To justify their political arguments and decisions politicians must produce discourses that are convincing. They therefore need to invoke ideas that are dominant and shared among the audience to gain their confidence. Even if the Troika was imposing policies, it was not expressing itself in the national political discussion, hence, 'the battle was viewed as a domestic political drama with leading national politicians playing the leading role’ (Alasuutari, 2016, p. 21).

Consequently, responsibility rested with the politicians as they were in charge of the changes in policies to comply not only with the agreed measures for the bailout, but also to honour the citizens (see e.g. Brunsson, 2007). The legitimacy of representative democracies is guided by the idea of popular sovereignty, which refers to the sufficient inclusion of citizens in the processes and discussions on acute political matters through public channels of communication, allowing citizens to control, influence and evaluate formal decision-making (Habermas, 1996). Accordingly, 
government politicians faced with the Troika’s intervention needed to deal simultaneously with the demands from the Troika and the demands of popular sovereignty, which causes contradictions. How do the actors manage to maintain their responsibility and legitimacy within both settings? One strategy is to evade their responsibility, in this case by making the decision or the role of the decision-makers less visible, by showing how they were compelled by external forces (Brunsson, 2007), for instance by means of depoliticized discourses. This strategy is a way to achieve some actions without losing support or legitimacy, because if they publicly avoid responsibility, they cannot not be blamed for it (Brunsson, 1993). Earlier research has also shown that in conflicting demands of various stakeholders another strategy to maintain legitimacy is hypocrisy (Cho, Laine, Roberts, \& Rodrigue, 2015). Decisionmakers may find themselves 'handling conflicts by reflecting them in inconsistencies among decisions and actions’ (Brunsson, 2007, p. 115). Hence, national decisionmakers may apply the demands of the IOs, but without exactly articulating them. This may cumulate in policies 'being done without their being openly accounted for' (Brunsson, 1993, p. 492). However, as Cho, et al. (2015) have asked: how can they continually engage in hypocrisy and maintain any legitimate standing within the organization or within society? One answer to that is the organizational façades, 'a symbolic front erected by organizational participants designed to reassure their organizational stakeholders of the legitimacy of the organization and its management' (Abrahamson and Baumard, 2008, p. 437). As Abrahamson and Baumard (2008) suggest, there can be more than one façade to serve different roles in managing different stakeholders. In our analysis we will be looking at two separate institutional façades from the perspective of interactional research. It turns out that within these contexts 
politicians change the content of what they say and act out different roles of responsibility for a different set of primary recipients (see Goodwin, 1981).

Schmidt (2006) has proposed two main domains of political discursive interactions: the ‘coordinative discourses’ among policy actors in constructing, arguing, deliberating and reaching agreement on policies and the 'communicative discourse' between political actors and the public engaged in presenting, explaining and legitimating those policies. Although these domains are interconnected in terms of substantive content and interactive process, they do not always connect with one another (Schmidt, 2006). Schmidt (2014, p. 188) has also noted that EU level politicians use different discourses depending on the audience: other decision-makers, the markets or the people. 'Who is speaking, to whom, about what, where and why' (Schmidt, 2015) seems to be relevant in the interactive practices of political discourse. In a similar vein, Maingueneau (2010) has formulated the idea of types of discourses understood as sets of measures and norms of communication through which speech can be articulated and legitimized in a specific place and at a specific moment. Discourses are defined in terms of situational criteria in which the role of the participants, the purpose, the medium and the time-space framework are criteria for the spokesperson (Charaudeau, 1995; Maingueneau, 1996, 2010). Aligning with these thoughts, we will show that political discourse is indeed, 'recipient designed' (Sacks, Schegloff, \& Jefferson, 1978) to convince the target audience. These situated recipient designs include various forms of normative address and anticipations which work on achieving institutional appropriateness and responsibility (Rautajoki, 2014). Our research demonstrates that the management of institutional legitimacy is sensitive to communicative occasions.

Within a political environment fraught with competing normative pressures politicians can adopt different strategies to maintain their responsibility and legitimacy 
(Rautajoki, in process). Even in the case of forceful Troika intervention decisions are ultimately submitted to parliamentary discussion and are voted on. In this paper we will show that no matter if the decisions made and actions taken stay the same, the talk to justify them can differ to manage the impression imparted to the general public and achieve legitimacy in different communicative settings. How, then, do politicians operate on variable justifications in specific situations?

To make appropriate claims and give valid accounts government actors need to consider what shall be deemed legitimate and how to legitimise their decisions to others at the level of local practices (Schmidt, 2016). Legitimacy and power are gained and maintained through actions, discourses and ideas. As pointed out in research, ideas matter in politics (see e.g. Jacobs, 2009; Schmidt, 2008) and influence policy outcomes (Béland and Cox, 2016). Ideas have a certain relevance or power when actors seek to promote their own ideas at the expense of others (Carstensen and Schmidt, 2016). Carstensen and Schmidt (2016) have pointed out three types of ideational power: power through ideas (italics in the original) as the capacity to convince other actors to accept certain views by using ideational elements; power over ideas (italics in the original) as the imposition of power to resist the inclusion of alternative ideas; and power in ideas (italics in the original) as ideational power, in other words, the authority certain ideas enjoy in structuring thought at the expense of other ideas. With our empirical case we can see how these three types are intertwined, as the intervention of the Troika in Portuguese politics already entailed a disparity regarding actors and their use of power to intervene in national policy-making. The coercive power that the Troika exerted in the bailout countries already implied a capacity to impose certain ideas and conditions without resorting to persuasion - that is, power over ideas (Carstensen and Schmidt, 2016). 
However, national politicians had the last word, as the measures imposed needed to be discussed and allocated to national policies and reforms. Therefore the national government needed to further the ideas from the MoU and introduce them through reasoning or argument, that is, wielding power through ideas, as power over ideas can always be challenged and contested (Carstensen and Schmidt, 2016). At the same time, a political actor, for instance from the opposition, is able to question the ideas imposed or the arguments of the government likewise by using power through ideas (Carstensen and Schmidt, 2016). By this means, actors try to introduce new ideas into the policy programme. The key element in this type of ideational power is persuasion, as the power is based on the capacity of actors to influence others through argumentation. It is not enough to invoke ideas; actors need to believe in them to have the ability to persuade through them. Moreover, actors can imbue their discourses and ideas with more power by connecting them with powerful ideas as such. That is, actors may incorporate ideas in their discourses that already enjoy authority (Carstensen and Schmidt, 2016). Power in ideas could be seen as even more 'powerful' than coercive power; for example, to appeal to the nation and the citizens, to the common good or national sovereignty; or on the contrary, to invoke the imperative constraints in which they are immersed. In our research we connect the domestication framework with power through ideas and epistemic governance. We argue that external coercion is tamed discursively to appeal and persuade the rest through epistemic governance. In controversial political situations, the power that actors are able to exert through and in ideas is fundamental to contest and justify these compulsory measures (power over ideas) and to build legitimacy around the ideas proposed (Blyth, 2002). 


\section{Data and Methods}

To examine how government politicians handle the aspect of coercion in their national political discourse when they are in receipt of conditional financial support, we present Portugal within the Troika bailout as a case study. Portugal experienced an increased fiscal deficit and debt in relation to Gross Domestic Product (GDP) in 2009, which led to rising pressure on the interest rates and a reduction in the demand for government bonds (Freire, Lisi, Andreadis, \& Leite Viegas, 2014). In April 2011 Portugal, which was governed by the Partido Socialista (PS) in a minority government, was unable to meet the rising debt commitments and became the third European Union Member State to request financial assistance from the Troika (Cardoso and Branco, 2018). The MoU was negotiated during the electoral campaign and afterwards implemented by a coalition government composed of the Partido Social Democrata (PSD) and the Centro Democrático Social- Partido Popular (CDS-PP) (Moury and Standring, 2017). The austerity measures imposed in this international intervention had a significant impact on the labour market in Portugal: wage devaluations, reversal of working-time gains, flexible labour market practices (Costa, 2012), but also on the health care system (see Legido-Quigley et al., 2016) or the welfare system, with pension rights significantly restricted and welfare benefits less generous and more conditional (Zartaloudis, 2014). In May 2014 Portugal ended with the assistance programme. Although Portugal was not the only country audited by the Troika, we have chosen the case due to its special characteristics. The Portuguese government had to cope not only with the increasing resistance of the population, but also with the Constitutional Court as a veto player during these three years invalidating some of the policy proposals (Baraggia, 2015; Magone, 2014; Moury and Standring, 2017). Yet Portugal was considered ‘the Troika’s 
good pupil', who implemented the required policies with the minimum of fuss and delay (Magone, 2014, p. 353).

We will demonstrate the alternating use of rhetorical tools by focusing on two types of communicative environments: parliamentary debates and media reports. We gathered the parliamentary debates on the Lei do Orçamento do Estado (State Budget Bill) at the time of the Troika intervention in Portugal - namely from June 2011 until May 2014. For this study we analysed 13 floor debates. We also gathered direct reports of speeches of politicians in the media during the Troika intervention in two generalist quality daily newspapers: Público, Diário de Notícias and one quality daily economics newspaper: Jornal de Negócios. We searched for items directly reporting politicians' speeches to make sure that these were explicit political talks, analysing 54 items in total. All the documents analysed are public and easy to access through the parliamentary online data archive and the newspapers’ online archives. Although the discourses were from the same speakers (the national politicians in charge) in the same anomalous situation (intervention by the Troika), these data sets represent two communicative environments in which activity orientation and the constellation of participants differ from each other: while in parliamentary debates the aim is to debate and discuss the national policies among peer politicians, in political reports and press conferences the goal is to explain the decisions and national policies to the general public. Moreover, these two environments represent two different institutional systems within democracy.

The analysis proceeded in three stages. In the first stage, both data sets were scrutinized by applying tools from discourse analysis (DA) (Fairclough, 2003; Wood and Kroger, 2000) conversation analysis (Sacks, et al., 1978) and research on institutional interaction (Drew and Heritage, 1992). In this study DA was understood and used as an empirical method to analyse how through language people give 
meanings to certain affairs, and how some discourses gain acceptance as a way to construct political arguments. We used DA to place special emphasis on the persuasive and rhetorical aspects of the discourses (Potter, 1996) explicating the ways in which the discourses are produced in order to be persuasive (Billing, 1996). Discourses were approached in their interactional setting, in which actors perform institutional actions and talk institutions into being (Heritage and Clayman, 2010). Thus, besides discursive formulations, we paid attention to the communicative purposes of the talk. To facilitate our analysis, we used ATLAS.ti to organize and code the data.

In our analysis we coded three aspects: 1) the communicative area in which the statement was made: in parliament or in public accounts in the media; 2) the role of the politician making the statement, focusing the attention on the government actors; 3) the justifications and arguments put forward in their statements. In analysing the justifications, we paid attention to the various discursive strategies politicians used to construct their arguments and to what purpose. Here the interest was not to test any preestablished categorization, but rather to inductively identify different ways by which the obligations are presented and justified in the national discussion. Following another principle in qualitative research, the aim was to create a categorization that applies to all types of justifications (Alasuutari, Bickman, \& Brannen, 2008), but without being mutually exclusive, as a statement may include several parallel typologies. In the second stage, we proceeded to identify several key terms and expressions that were broadly related to the different rhetorical strategies identified. After identifying the terms and expressions, we proceeded (third stage) to evaluate their frequency of occurrence $^{1}$ and their interrelation with the communicative arena. The purpose of this

\footnotetext{
${ }^{1}$ Although the frequency of occurrence was done by keyword searches, not all the words and expressions were always counted. Rather, we made sure that the term or expression appeared as part of a justification; in that sense, we have excluded from the analysis the statements where certain terms appeared in contexts where the purpose was different (i.e. the term 'emergency' as part of the 'programme of social
} 
stage was to compare both corpora and to show the distribution of rhetorical strategies therein. Although following the logic of action within the political field, the opposition influence politics by rebutting the government's arguments, and at the same time, their discourses and criticisms need to be taken into account by the government; in the national sphere the government in office is the one in defence of policies, with ultimate political control and responsibility. Therefore, in this paper we only analyse and present the results on the government actors to build our argument.

\section{Political Justifications of Coercion}

In this empirical section we analyse the various discourses and justifications employed by government actors. Although previous research has demonstrated how coercion tends to give rise to the tactics of depoliticization in political discourse, our analysis reveals that the responses to the coercive context by government actors were manifold and strategic in terms of building legitimacy. Our findings suggest that we can distinguish two types of justifications in regard to coercion: depoliticization, and relativization, both of them characterized by a series of discourses, terms and rhetorical expressions (see Tables 1 and 2).

[Tables 1 and 2 near here]

These forms of justification are not mutually exclusive. Rather, they are analytic categories set apart by the main emphasis of the utterance and they tend to co-occur in political talk. However as Figure 1 shows, these two types of justifications were not equally frequently present in the communicative environments. While the majority of

emergency', or the term 'constraints' as part of the 'I will deliver my statement fast because of time constraints' etc.). 
the justifications of relativization appeared more prominently in the parliamentary debates (86\%), the justifications of depoliticization were recurrent in the media (61\%) (see Figure 1).

[Figure 1 near here]

Hence, we argue, that in the two arenas the communicative uses and purposes of justifications are not the same. Next, we explain and illustrate both strategies by analysing how and when the justifications are deployed.

\section{Depoliticizing Discourses}

In a context of economic intervention such as the case studied here, there were undeniably constraints in the political domain. The government could invoke the Troika and its ideas when the opposition challenged the political programme (Standring, 2018) or even to implement changes that they wanted to accomplish (see Moury and Standring, 2017). There are many discursive tactics to address depoliticization, probably the best known being the slogan 'there is no alternative' (TINA), in which the politicians allude to their incapacity to act differently (Watson and Hay, 2003). Others include the explicit invocation of constraints, necessity, inevitably or irrefutability (Séville, 2017).

In this section, we study how and when government actors employ tactics of depoliticization. In the analysis we noticed that depoliticized discourses did indeed gain acceptance as a way to construct political arguments during the intervention by the Troika. This way politicians seemed to domesticate the obligations and incorporated them into daily discourses making them seem part of the natural ways to discuss and 
approach the intervention. However, we found that these ploys were more frequent in political reports when government actors explained and justified political decisions in the media than they were in the parliamentary debates. It was in these contexts that they were inclined to publicly abandon or mitigate their responsibility (Avigur-Eshel, 2018). The government politicians constructed a discourse depicting that they were under duress, that they had no alternative and that these policies were inevitable in their efforts to justify the unpopular austerity measures. They employed them to convince the general public of the prevailing dire circumstances, insisting that these measures were the right ones in this situation. As stated, the procedural legitimacy of representative democracy derives from popular sovereignty, that is, from sufficient inclusion of citizens in decision-making practices through public discussion (Habermas, 1996, pp. 315-316). The discursive tactics of depoliticization can be used 'as a means of insulating oneself from public criticism in moments of reforms, revisions or potential policy change’(Séville, 2017, p. 464).

In our analysis we identified four different discourses of depoliticization in the arguments. Of these four discourses, the first one can be called the discourse of external constraints, within which actors justify and emphasise the absence of alternative. The second is the discourse of political reluctance. In this discourse, actors emphasise the unpopularity and drawbacks of the measures, arguing that it is not what they would have wished. The third is the discourse of negative consequences. In this discourse, actors want to demonstrate the importance of complying with the Troika mandate as the consequences of not doing so could be worse. The fourth can be called the discourse of exceptional circumstances. Within it, actors argue that they are in an unusual situation requiring urgent and rigorous measures. Although these four analytical categories represent different rhetorical strategies, they all present similar nuances and ideas that 
are intertwined: they emphasize the anomaly of the situation and the political impossibility of going in another direction.

\section{Discourse of External Constraints}

The quotes below show politicians stating clearly that they have no alternative but to comply with the Troika requirements. The first quote is from the beginning of the intervention, in autumn 2011, at the very moment when government politicians most needed to justify the intervention and the importance of applying the measures stipulated in the MoU. The quote below shows how Passos Coelho (PSD), the Prime Minister at the time of the Troika intervention recognized publicly the harsh measures of the government and explained and justified them by claiming that they were the only possible solution as the government was limited to the bailout agreement.

The 'measures of a horizontal nature' applied to State workers and pensioners, in particular the suspension of holiday and Christmas allowances, 'are extremely harsh', but 'there is no alternative to this path', said Prime Minister (Passos Coelho) on Tuesday during the final words of a conference of Diário Económico dedicated to the challenges of the State Budget for the coming year. As for the discussion of the State Budget proposal for the upcoming year, Passos Coelho stresses that, as regards 'fundamental issues' and 'more controversial measures', there is 'no room to negotiate' with the Socialist Party, as the 'basic policies are conditioned by the financial rescue package established with the International Monetary Fund and the European Union’ (Diário de Notícias, 25 October 2011). 
Interestingly, not all these justifications of the measures were from the beginning of the intervention. They persisted as a recurring argument throughout the Troika period.

Deputy Under-Secretary of State, Carlos Moedas, insisted this Friday that 'there are no viable alternatives' to the Portuguese adjustment, which have to be 'followed' to be able to resume a 'balanced' financial situation. According to the official, 'we are living in difficult times' and 'we are all aware that the process entails sacrifices and uncertainties, but it has to be followed by Portugal in order to return to a certain economic balance’' (Público, 9 November 2012).

For instance, in the quote above from 2013, a PSD politician maintained that although Portugal was facing difficult times, the adjustments and sacrifices were the only possible way to overcome the crisis.

\section{Discourse of Political Reluctance}

This notion of having no choice could also be emphasized with the idea of seeking a different solution or by stating categorically that if there were room to manoeuvre the decisions would be different. In that sense, it was a shared discourse to go a step beyond the argument of 'no alternative' and demonstrate that their political wishes were not these. The quote below shows how the Prime Minister justified the measures decided on by acknowledging their roughness and claiming that they were not their political aspiration but that they had no other option.

'We have nothing against civil servants, but the State does not have the money to sustain the wage bill that we have with the civil servants,' said Prime Minister Passos Coelho this afternoon, when confronted by journalists with the strike 
scenario in the civil service and with the accusations that it is backing down on a promise made in the electoral campaign of not dismissing civil servants. The Government seeks an 'agreement as broad as possible' and acknowledges that the current situation is 'difficult for unions and workers'. We are 'working on the situation', but 'we do not have a magic wand to say that the problems will be solved miraculously’. (Jornal de Negócios, 30 May 2013).

The idea of emphasizing the unwillingness of these policies appears in the parliamentary debates intertwined with some other ideas and justifications, although they are not as direct as in the media.

It is in this context that we arrive at the decision, which is hard and unpopular but inevitable, and taken with courage and determination, of suspending Christmas subsidies and paid holidays for public officials, pensioners and the state business sector, for salaries above $1000 €$ per month, and to reduce, on average, one of these subsidies between the minimum wage and that value. This is for the duration of the adjustment programme.

It is, of course, the measure that characterises this State Budget, although it is not unprecedented in Portugal. In fact, already in the Budget for 2011, when the Socialist Party was in power, the salary costs of the public sector and the state business sector were cut (PSD, Parliament of Portugal, 11 November 2011, p. 36).

The example shows how a Member of the Parliament (MP) of the governing party highlights the idea that the political and economic context was the cause of the hard decision. Yet, while conceding the unpopularity of the measure, the speaker also goes a 
step further in the argumentation by claiming that the previous government did something similar, thereby demonstrating that the measure is not unprecedented.

\section{Discourse of Negative Consequences}

Another recurrent strategy of depoliticization in the political discourses was to rationalize the obligations by presenting the necessity to comply with them. In this case, the idea was to scare the audience by announcing that the consequences of not following the path would be worse.

\footnotetext{
'If Portugal does not comply with the programme, the alternative will be worse,' says Marques Guedes (Público, 7 November 2013).
}

The extract illustrates how a government spokesman (PSD) uses this strategy to warn the general public of the importance of compliance to overcome the intervention and to justify the decisions taken as appropriate in the situation. By stressing the negative effects of not obeying the MoU, government politicians reinforced the idea of there being no alternatives.

\section{Discourse of Exceptional Circumstances}

Moreover, alluding to the exceptional times that the state was facing and the exceptional measures required was another shared and used discourse occurring for the entire duration of the intervention. By considering this situation as an anomaly the speakers constructed a scenario out of the national perspective, with no other options than to meet the international requirements. 
The first vice-president of the PSD (Jorge Moreira da Silva) stressed that this moment requires us to fulfil the obligations assumed with the international creditors and to do what has to be done and not what would be 'easier' (Jornal de Negócios, 5 October 2012).

In this case a government actor (PSD) argues that the exceptional situation that Portugal was facing demanded compliance with the Troika.

\section{Relativization of the Troika's Intervention}

Although one might assume that national decision-makers must adhere to the bailout agreement with virtually no opposition or consideration, the national parliaments nevertheless have the legal authority to approve or reject bills. Whereas the discourses of depoliticization were commonly employed in the media reports, in parliamentary debates the predominant strategy was to show that the local actors did indeed play a role and exert influence in the political processes. Therefore, MPs of the governing party discussed and justified their views by appealing to powerful ideas in order to persuade other politicians regarding the situation and the appropriate course to take (Alasuutari, 2016, pp. 113-114). They did not directly promote what was said and agreed in the MoU or justify the absence of political options as was often the case in the public discourses in the media, rather they used and incorporated the Troika intervention as part of the ongoing political discussion to further their own arguments and objectives. In that sense, while government actors might be in favour or against the Troika proposals, or even pressured to incorporate them, they converted the Troika demands into justifications for their own purposes, while trying to convince other politicians to gain maximum support for their views. In this discursive arena the arguments are not as black and white as they tended to be when explaining the decisions and the reasons for 
them in the media. MPs of the governing party endeavoured rather to relativize the Troika intervention to construct convincing discourses and arguments for the other MPs or at least less easily refutable claims. In that sense, the government politicians employ strategies of relativization to show their capabilities to their fellows and their credibility to work for the national interest.

In our analysis we identified four different ways of relativizing the Troika and the MoU in the arguments. Of these four discourses, the first can be called the discourse of national improvement. Here actors proclaim how the nation's performance has improved through the Troika bail-out. The second is the discourse of national responsibility. In this discourse, actors argue how, despite being bailed out they are acting in favour of the nation and its interests. The third is the discourse of national choice. In this discourse, actors want to demonstrate how they still have room to manoeuvre, to choose and make decisions. The fourth can be called the discourse of national guilt. Here actors argue that this situation is not attributable to the Troika. Although these discourses are much more frequent in the parliamentary debates, we also found some traces of them in the media texts. Even though these four analytical categories represent different rhetorical strategies, they display a similar correlation: they stress the capacity of action of the national government and how this is always exerted to benefit the nation.

\section{Discourse of National Improvement}

One way to relativize the international intervention was to show the positive side - that is that in this situation the nation progressed. Many MPs from the government party, substantiated their arguments by saying that the Troika evaluations were positive, proposing to continue along the same line. MPs wanted to emphasise that their political 
actions in this international intervention were bearing fruit, and despite being in a hard or unpleasant situation, they could be proud of how they were progressing. As seen in the quote below, an MP from the government party is arguing for the importance of highlighting the great job that all the Portuguese and the government were doing to fulfil the international commitments. In that sense showing the importance of continuing on the same track.

All the evaluations made by the Troika are positive and this is the work of this Government and of all the Portuguese (PSD, Parliament of Portugal, 30 October 2012, p. 29).

The main purpose in adhering to the Troika guidelines was to overcome this situation as soon as possible and to start again with full sovereignty. In this case, MPs were not asking how they had arrived at the actual situation, rather they stressed that the main thing was to cope with it. This discourse gained importance throughout the period as a way to demonstrate that this intervention would not last forever and that the best way to start again with normal political control would be to fulfil the terms of the MoU. Furthermore, apart from re-establishing full control of the economy, actors also emphasised that the ultimate goal was to restore the image, credibility and reputation of the nation.

We will contribute to the reduction of the financing costs of the Portuguese State and the Portuguese economy in the future; we will be releasing resources that are now consumed by servicing debts. Next year, we will exceed 8,000 million euro; we will honour our sovereign signature; we will be making a very valuable contribution to the advancement of the European project; we will be 
demonstrating the responsiveness of our democracy and our institutions even in the face of such serious emergencies as this. It is a difficult task, but it is also a noble task and with very clear rewards (PSD, Parliament of Portugal, 11 November 2011, p. 62).

The excerpt illustrates how an actor argues and stresses the importance of continuing along this line of compliance. In that sense, going along with the Troika is the means to achieve and regain the reputation, which is in the public interest.

\section{Discourse of National Responsibility}

Another way of relativizing the Troika's intervention was to emphasise the legitimacy of the parliament and the importance of governing for the nation and its citizens as a national responsibility. In this case, MPs wanted to make it entirely clear that they do not take political decisions thinking of the Troika and pleasing it; actors rather justified their decisions by claiming to be thinking of the nation.

We think of the Portuguese people, not the Troika so, after this stage, and having successfully completed the necessary adjustments, we can definitely open a horizon of hope for all. It is to think of all the Portuguese who are in difficulties, not in the name of the Troika, nor of any ideological dictates, ... (Prime MinisterPassos Coelho (PSD), Parliament of Portugal, 30 October 2012, p. 9).

As the quote above shows, this talk was prevalent in the government's interventions as a way to justify their measures and actions, which were always intended to benefit the nation. 


\section{Discourse of National Choice}

In some other cases actors evoked the Troika to show that they were not powerless in this situation and that they had room to manoeuvre to pursue political ends. In other instances, MPs emphasised that they were pursuing the policies that they considered to be in the nation's best interests.

Do you know why? Because this did not seem possible, nor socially acceptable. This is precisely why we opposed the Troika in this matter and, in that sense, we have found a solution that is, from the social point of view, more defensible (PSD, Parliament of Portugal, 26 October 2012, p. 12).

Some of these could be policies not included in the MoU or even policies that were contrary to what the Troika was saying. In that sense they relativize the impact of the Troika by saying that they are actual political agents, as seen in the quote above.

\section{Discourse of National Guilt}

Finally, another discourse in which actors relativized the Troika was to demonstrate how the fault is not with the Troika, but rather with the nation. In these discourses, government politicians actually acknowledged their critical situation by discussing how they had arrived at that point. In the parliamentary discussion it is hardly usual to blame the IO (cf. Schmidt, 2007; Traber, et al., 2016). Instead, an acceptable discourse to construct arguments is to allocate the blame to other national actors or even the past, as seen in this example from the government:

We have heard Mr. Silva Pereira say that the Portuguese do not forget, I would like to say to the former Minister that I believe that the Portuguese do not forget. The Portuguese do not forget that it is the biggest failure that a government can 
have, which is to put Portugal to the humiliation of having to negotiate with international creditors to decide what their deficit and budget is, because it ceased to be sovereign, to have independence to finance itself in international markets (CDS-PP, Parliament of Portugal, 25 October 2013, p. 44).

Blaming the past or the former government may also occur as a discursive strategy in the media. The extract below illustrates how the Prime Minister acknowledges his responsibility in the harsh measures but stresses that he would have not imposed them without the legacy of the past government, which actually requested the bail-out. Therefore, here again the actors were stressing the role of the government actors as true agents.

Passos assumes violence of austerity but blames the socialist inheritance: 'The measures are mine, but the deficit that compels them is not mine' (Público, 15 October 2011).

To conclude, our empirical analysis shows that when there is a coercive setting a strategic choice is made as to how to argue and justify the policies. We found two varieties in the data: depoliticization and relativization. Government politicians domesticated the Troika's intervention differently in different communicative environments, which goes to show that the same institutional actors deploy diverse discursive strategies in persuading the audience in these arenas. On the one hand, they relativized and mitigated the Troika and its ideas to influence other politicians in the field of national policy-making. We suggest that in parliamentary debates it is not so common to find depoliticized discourses in which actors try to limit the reasoning and impose imperative ideas, because these are rather weak. Depoliticized discourses suggest powerlessness in political deliberation and can easily be contested. Instead, 
politicians must build well-justified arguments that can convince their peers about the best options. In that sense, government politicians use their capabilities and agency to balance the threat and work for the nation, suggesting ideas that can be in concord with the national trajectory. On the other hand they evoked the tactics of depoliticization as a way to evade responsibility and defend themselves against public criticism for what could be considered unpopular policies.

\section{Conclusions and Discussion}

In this paper we set out to examine how government actors of a nation-state cope with coercion exerted on them by an external source and how they evolve justifications and persuasive arguments when debating and reporting new policies in a setting that threatens to compromise national sovereignty and integrity. We studied the case of intervention by the Troika in Portugal (June 2011- May 2014) by analysing two datasets: parliamentary debates on State Budget bills to study the discourses used in political deliberation, and direct reports of speeches of politicians in the media to study the discourses employed when communicating and explaining the situation and the new policies to the general audience.

The analysis shows that depoliticization is not the only strategy activated by coercion. Politicians operate on morality, anticipate the expectations of the audiences and accordingly assign themselves the appropriate roles and responsibilities in an interactive setting (see Rautajoki, 2012). Our study reveals that coercion was handled differently by the same speakers depending on the communicative environment through adopting different discursive strategies: depoliticization and relativization. The discourse of depoliticization was very prominent in the public arena, whereas the argumentation in the parliamentary debates underlined the aspect of agency and 
capability - that is mitigating and relativizing the force of the Troika and its intervention in the state by expounding national improvement, national responsibility, national choice and national guilt. We argue that the reason for the variation in the strategies used in different arenas was that the persuasion was designed for different publics and for different purposes with different principles of legitimate action. In the parliamentary debates the strategy was not to limit the political contestation, but rather to work on the best arguments to persuade the other politicians towards agreement and influence the political deliberation. By contrast, in the public arena, when explaining the policies and decisions of the parliament to the general audience, the strategy employed was to highlight the exceptional nature of this situation and the lack of political options, which serves to uphold the trustworthiness of the representatives in the eyes of the public by removing the political character in these difficult circumstances from the government to lay it at the door of the international creditors. Both strategies safeguard the integrity of the nation, only in diverse discursive arenas the actors choose different strategies to portray rationality and responsibility (Alasuutari, Rautajoki, Auvinen, \& Rautalin, 2018). Government politicians achieved this, firstly by highlighting the remaining power and agency in front of other politicians, and secondly, by emphasizing the imperative to execute the Troika mandate in order to overcome the crisis for the citizens.

Our analysis indicates that government politicians actually downplayed the power of the Troika when debating the policies and manifesting their own political capability and agency in the process (cf. Borriello, 2017). Research on national politicians making use of the IOs’ recommendations on a voluntary basis have demonstrated that politicians may deploy the rhetoric of coercion to strengthen their arguments and to influence domestic policy-making by giving the impression that they 
are forced to proceed with certain exogenous ideas (see Alasuutari, 2016; Alasuutari, Rautalin, \& Syväterä, 2016; Rautalin, Alasuutari, \& Vento, 2018). It has also been stated that the use of coercion as a rhetorical tool in political deliberation tends to vary: in situations where politicians are in fact subject to coercive power they avoid mentioning it and frame the ideas imposed as part of their own interest, whereas in other circumstances, without implicit pressure, they may construct coercion as a rhetorical tool (see also Alasuutari, 2016).

Furthermore, our study contributes to the theoretical understanding of political persuasion by illustrating how domestication is a procedural as well as an institutional tactic in legitimation. It makes the outer ideas 'ours' but they have to accomplish this task on different battlefields with diverse compositions of relevant participants. In this vein we argue that government politicians use different rhetorical tools to persuade and convince different recipients and to salvage their legitimacy within each framework. Government actors need to demonstrate responsibility to attain institutional legitimacythat is, they need to be scaling the normative expectations within each arena. As we have demonstrated in our paper, it is not the same thing to address the media public, the citizens on whom the policies will have an effect, as it is to address discourses to fellow politicians. Neither is the communicative context in which the discourse takes place the same: the discourses produced to debate and decide the policies are different from the discourses produced to explain and report the decisions already taken. Hence there are different kinds of arenas of responsibility and accountability the governing politicians must handle in a coercive setting (see also Rautajoki and Pi Ferrer, in process). The relational scaffolding of the arguments, that is, the logic of interrelations, activities, mutual rights and obligations is different in them, and these interrelations guide the discursive strategies actors choose to achieve legitimacy for their actions (Rautajoki, in 
process). We argue that epistemic governance and political persuasiveness are always relational: although the message may be the same, actors formulate it differently depending not only on the recipient but also on the institutional system in which the speech is produced.

Although our coding is reasonable with this data and for the purposes of this study, we assume that these discourses are not exclusive and we acknowledge that there may also be additional nuances and strategies at play in navigating coercion. However, our analysis does present a demonstrable variation in justifications within a single case study. Moreover, we would expect to find similar discursive mechanisms in other countries dealing with external coercion. In this respect, further research could be done to see, for instance, whether other bailout countries acknowledged to present more controversies in compliance with impositions present different rhetorical patterns. Future research could also broaden the perspective and explore how international actors are addressed in political talk on the Troika impositions. This paper has concentrated on the national level discussion in two political communication settings to evidence the deployment of legitimacy with discursive strategies beyond depoliticization.

\section{References}

Abrahamson, E., \& Baumard, P. (2008). What lies behind organizational façades and how organizational façades lie: An untold story of organizational decision making. In G. P. Hodgkinson \& W. H. Starbuck (Eds.), The Oxford handbook of organizational decision making (pp. 437-452). Oxford: Oxford University Press.

Alasuutari, P. (2016). The Synchronization of National Policies: Ethnography of the Global Tribe of Moderns. London: Routledge. 
Alasuutari, P., Bickman, L., \& Brannen, J. (Eds.). (2008). The SAGE handbook of social research methods. Thousand Oaks, CA: Sage.

Alasuutari, P., \& Qadir, A. (2014). Epistemic governance: An approach to the politics of policy-making. European Journal of Cultural and Political Sociology, 1(1), pp. 67-84.

Alasuutari, P., \& Qadir, A. (Eds.). (2013). National policy-making: Domestication of global trends. London: Routledge.

Alasuutari, P., Rautajoki, H., Auvinen, P., \& Rautalin, M. (2018). Shattering the Single European Sky: Argument from authorities in dealing with the SES initiative. European Journal of Cultural and Political Sociology, pp. 1-27.

Alasuutari, P., Rautalin, M., \& Syväterä, J. (2016). Organisations as epistemic capital: the case of independent children's rights institutions. International Journal of Politics, Culture and Society, 29(1), pp. 57-71.

Armingeon, K., \& Baccaro, L. (2012). Political economy of the sovereign debt crisis: The limits of internal devaluation. Industrial Law Journal, 41(3), pp. 254-275. Avigur-Eshel, A. (2018). Synthesizing depoliticization and responsibilization: The case of financial education in Israel. Competition \& Change, p 1024529418798115.

Baraggia, A. (2015). Conditionality measures within the Euro area crisis: A challenge to democratic principle? Cambridge Journal of International and Comparative Law, 4(2), pp. 268-288.

Béland, D., \& Cox, R. H. (2016). Ideas as coalition magnets: Coalition building, policy entrepreneurs, and power relations. Journal of European Public Policy, 23(3), pp. 428-445.

Billing, M. (1996). Arguing and thinking: A rhetorical approach to social psychology (2nd ed.) Cambridge: Cambridge University Press. 
Blyth, M. (2002). Great Transformation: Economic Ideas and Institutional Change in the Twentieth Century Cambridge: Cambridge Press.

Borriello, A. (2017). 'There is no alternative': How Italian and Spanish leaders discourse obscured the political nature of austerity. Discourse \& society, 28(3), pp. 241261.

Brunsson, N. (1993). Ideas and actions: Justification and hypocrisy as alternatives to control. Accounting, Organizations and Society, 18(6), pp. 489-506.

Brunsson, N. (2007). The Consequences of Decision-Making Oxford: Oxford University Press.

Cardoso, D., \& Branco, R. (2018). Liberalised dualisation. Labour market reforms and the crisis in Portugal: A new departure. European Journal of Social Security, 20(1), pp. 31-48.

Carstensen, M. B., \& Schmidt, V. A. (2016). Power through, over and in ideas: conceptualizing ideational power in discoursive institutionalism. Journal of European Public Policy, 23(3), pp. 318-337.

Carstensen, M. B., \& Schmidt, V. A. (2017). Power and changing modes of governance in the euro crisis. Governance

Charaudeau, P. (1995). Une analyse sémiolinguistique du discours. Langages, pp. 96111.

Cho, C. H., Laine, M., Roberts, R. W., \& Rodrigue, M. (2015). Organized hypocrisy, organizational façades, and sustainability reporting. Accounting, Organizations and Society, 40, pp. 78-94.

Costa, H. A. (2012). From Europe as a model to Europe as austerity: the impact of the crisis on Portuguese trade unions1. Transfer: European Review of Labour and Research, 18(4), pp. 397-410. 
Culpepper, P. D. (2014). The political economy of unmediated democracy: Italian austerity under Mario Monti. West European Politics, 37(6), pp. 1264-1281.

De Ville, F., \& Orbie, J. (2014). The European commission's neoliberal trade discourse since the crisis: Legitimizing continuity through subtle discursive change. The British Journal of Politics and International Relations, 16(1), pp. 149-167.

Diário de Notícias (2011, 25 October). Passos Coelho alega que "não há alternativa"aos cortes. https://www.dn.pt/

Drew, P., \& Heritage, J. (1992). Analyzing talk at work: An introduction. In P. Drew \& J. Heritage (Eds.), Talk at Work (pp. 3-65). Cambridge: Cambridge University Press.

Fairclough, N. (2003). Analysing discourse: Textual analysis for social research London: Routledge.

Featherstone, K. (2015). External conditionality and the debt crisis: the 'Troika' and public administration reform in Greece. Journal of European Public Policy, 22(3), pp. 295-314.

Flinders, M., \& Buller, J. (2006). Depoliticisation: Principles, tactics and tools. British Politics, 1(3), pp. 293-318.

Fonseca, P., \& Ferreira, M. J. (2015). Through 'seas never before sailed': Portuguese government discursive legitimation strategies in a context of financial crisis. Discourse \& Society, 26(6), pp. 682-711.

Fonseca, P., \& Ferreira, M. J. (2016). Paulo Portas e a legitimação discursiva das políticas de austeridade em Portugal. Análise Social, 51(4), pp. 886-921.

Freire, A., Lisi, M., Andreadis, I., \& Leite Viegas, J. M. (2014). Political representation in bailed-out Southern Europe: Greece and Portugal compared. South European Society and Politics, 19(4), pp. 413-433. 
Gago, A., \& Moury, C. (2017) Making and justifying impossible choices: Trade unions and Three-Level games in Ireland and Portugal. Paper presented at the 24th International Conference of Europeanists, Glasgow.

Goodwin, C. (1981). Conversational organization: Interaction between speakers and hearers New York: Academic Press.

Gorjão, P. (2012). Portugal and the straitjacket of the European financial crisis. The International Spectator, 47(4), pp. 64-68.

Habermas, J. (1996). Between facts and norms (W. Rehg, Trans.) Cambridge: Polity Press.

Haddon, L. (2007). Roger Silverstone's legacies: domestication. New media \& society, 9(1), pp. 25-32.

Hardiman, N., Spanou, C., Araújo, J. F., \& MacCarthaigh, M. (2019). Tangling with the Troika:‘domestic ownership’as political and administrative engagement in Greece, Ireland, and Portugal. Public Management Review, pp. 1-22.

Heritage, J., \& Clayman, S. (2010). Talk in action: Interactions, identities, and institutions Chichester: Wiley-Blackwell.

Jacobs, A. M. (2009). How do ideas matter? Mental models and attention in German pension politics. Comparative Political Studies, 42(2), pp. 252-279.

Jornal de Negócios (2012, 5 October). PSD considera discurso de Cavaco "realista e esperançoso". http://www.jornaldenegocios.pt/economia/detalhe/psd_considera_discurso_de_c avaco_quotrealista_e_esperanccedilosoquot.

Jornal de Negócios (2013, 30 May). Passos Coelho: “Estado não tem dinheiro para sustentar a factura salarial” da função pública. https://www.jornaldenegocios.pt/economia/financas- 
publicas/detalhe/passos_coelho_estado_nao_tem_dinheiro_para_sustentar_a_fac tura_salarial_da_funcao_publica.

Legido-Quigley, H., Karanikolos, M., Hernandez-Plaza, S., de Freitas, C., Bernardo, L., Padilla, B., .. . McKee, M. (2016). Effects of the financial crisis and Troika austerity measures on health and health care access in Portugal. Health Policy, 120(7), pp. 833-839.

Magone, J. M. (2014). Portugal is not Greece: policy responses to the sovereign debt crisis and the consequences for the Portuguese political economy. Perspectives on European Politics and Society, 15(3), pp. 346-360.

Maingueneau, D. (1996). Les termes clés de l'analyse du discours Paris: Le seuil.

Maingueneau, D. (2010). Le discours politique et son «environnement». Mots. Les langages du politique(94), pp. 85-90.

Matthijs, M. (2017). Integration at what price? The erosion of national democracy in the Euro periphery. Government and Opposition, 52(2), pp. 266-294.

Moury, C., \& Standring, A. (2017). ‘Going beyond the troika’: Power and discourse in Portuguese austerity politics. European Journal of Political Research, 56(3), pp. 660-679.

Parliament of Portugal (2011, 11 November). Aprova o Orçamento do Estado para 2012. Assambleia da República. http://debates.parlamento.pt/catalogo/r3/dar/01/12/01/040/2011-11$\underline{11 / 1}$ ?from $=2011-11-10 \&$ to $=2011-11-$ 12\&pPeriodo=r3\&pPublicacao $=$ dar\&pSerie $=01$.

Parliament of Portugal (2012, 26 October). Segunda Alteração ao Orçamento do Estado 2012. Assembleia da República. http://debates.parlamento.pt/catalogo/r3/dar/01/12/02/017/2012-10- 
26/3?from $=2012-10-24 \&$ to $=2012-10-$

26\&pPeriodo $=\mathrm{r} 3 \& p$ Publicacao $=$ dar $\& p$ Serie $=01$.

Parliament of Portugal (2012, 30 October). Aprova o Orçamento do Estado para 2013.

Assembleia da República.

http://debates.parlamento.pt/catalogo/r3/dar/01/12/02/018/2012-10-

$\underline{30 / 1}$ ?from $=2012-10-29 \&$ to $=2012-10-$

$\underline{30 \& p P e r i o d o=r 3 \& p P u b l i c a c a o=\text { dar } \& p \text { Serie }=01}$.

Parliament of Portugal (2013, 25 October). Segunda Alteração ao Orçamento do Estado 2013. Assambleia da República.

http://debates.parlamento.pt/catalogo/r3/dar/01/12/03/015/2013-10-

25/1?from $=2013-10-24 \&$ to $=2013-10-$

25\&pPeriodo=r3\&pPublicacao=dar\&pSerie $=01$.

Potter, J. (1996). Discourse analysis and constructionist approaches: Theoretical background.

Público (2011, 15 October). Passos assume violência da austeridade mas culpa herança socialista. https://www.publico.pt/2011/10/15/jornal/passos-assume-violenciada-austeridade-mas-culpa-heranca-socialista-23204837.

Público (2012, 9 November). Carlos Moedas: “Não há alternativas” ao ajustamento, mas “pode-se sempre afinar o rumo”.

https://www.publico.pt/2012/11/09/economia/noticia/carlos-moedas-nao-haalternativas-ao-ajustamento-mas-podese-sempre-afinar-o-rumo-1571795.

Público (2013, 7 November). "Se Portugal não cumprir o programa, alternativa será pior", diz Marques Guedes.

https://www.publico.pt/2013/11/07/politica/noticia/se-portugal-nao-cumprir-oprograma-alternativa-sera-pior-diz-marques-guedes-1611703. 
Rautajoki, H. (2012). Membership categorization as a tool for moral casting in TV discussion: The dramaturgical consequentiality of guest introductions. Discourse Studies, 14(2), pp. 243-260.

Rautajoki, H. (2014). Kasvokkain julkison kanssa: vastaanottajan multimodaalinen muotoilu televisiokeskustelun aloituksissa. [Facing the public. The multimodal recipient design in opening political TV discussions]. Media \& viestintä, 37(3), pp. 56-74.

Rautajoki, H. (in process). The relational scaffolding of justifications in discursive institutionalism. Deploying the double standard of European integration in negotiating a policy reform. Journal of European Public Policy

Rautajoki, H., \& Pi Ferrer, L. (in process). Shadowboxing in silence. Balancing with European Semester in National Parliamentary Debates on Economic Policies.

Rautalin, M. (2013). Domestication of International Comparisons: The role of the OECD Progamme for International Student Assessment (PISA) in Finnish educational policy (University of Tampere, Tampere University Press.

Rautalin, M., Alasuutari, P., \& Vento, E. (2018). Globalisation of education policies: does PISA have an effect? Journal of Education Policy, pp. 1-23.

Sacchi, S. (2015). Conditionality by other means: EU involvement in Italy’s structural reforms in the sovereign debt crisis. Comparative European Politics, 13(1), pp. 77-92.

Sacks, H., Schegloff, E. A., \& Jefferson, G. (1978). A simplest systematics for the organization of turn taking for conversation Studies in the organization of conversational interaction (pp. 7-55): Elsevier.

Schmidt, V. A. (2006). Democracy in Europe: The EU and national polities: Oxford University Press. 
Schmidt, V. A. (2007). Trapped by the ideas: French élites' dicourses of European integration and globalization. Journal of European Public Policy, 14(7), pp. 992-1009.

Schmidt, V. A. (2008). Discursive institutionalism: The explanatory power of ideas and discourse. Political Science, 11(1), pp. 303-326.

Schmidt, V. A. (2014). Speaking to the markets or to the people? A discursive institutionalist analysis of the EU's sovereign debt crisis. The British Journal of Politics and International Relations, 16(1), pp. 188-209.

Schmidt, V. A. (2015). Discursive institutionalism: Understanding policy in context. In D. Béland \& R. H. Cox (Eds.), Handbook of critical policy studies (pp. 171189). Oxford: Oxford University Press.

Schmidt, V. A. (2016). Reinterpreting the rules ‘by stealth’in times of crisis: a discursive institutionalist analysis of the European Central Bank and the European Commission. West European Politics, 39(5), pp. 1032-1052.

Séville, A. (2017). From 'one right way' to 'one ruinous way'? European Political Science Review, 9(3), pp. 449-470.

Standring, A. (2018). Depoliticising austerity: narratives of the Portuguese debt crisis 2011-15. Policy \& Politics, 46(1), pp. 149-164.

Streeck, W. (2014). The politics of public debt: Neoliberalism, capitalist development and the restructuring of the state. German Economic Review, 15(1), pp. 143-165.

Traber, D., Schoonvelde, M., Schumacher, G., Dahiya, T., \& de Vries, E. (2016) Issue Avoidance and Blame Attribution in Leader Speeches during the economic crisis in Europe. Paper presented at the 6th Annual Conference of the European Political Science Association, Brussels , 23-25 June. 
Watson, M., \& Hay, C. (2003). The discourse of globalisation and the logic of no alternative: rendering the contingent necessary in the political economy of New Labour. Policy \& Politics, 31(3), pp. 289-305.

Wood, L. A., \& Kroger, R. O. (2000). Doing discourse analysis: Methods for studying action in talk and text Thousand Oaks, CA: Sage.

Zartaloudis, S. (2014). The Impact of the Fiscal Crisis on Greek and Portuguese Welfare States: Retrenchment before the Catch-up? Social Policy \& Administration, 48(4), pp. 430-449. 


\section{Figure and Tables}

Tables 1 and 2: Justification of coercion in the political discourses

\begin{tabular}{l|l}
\hline \hline Depoliticizing discourses & Main terms and expressions \\
\cline { 1 - 2 } Discourse of external constraints & $\begin{array}{l}\text { no alternative, state of exception/ emergency, exceptionality, } \\
\text { complexity, extreme, controversial, conditioned, gravity, hard, } \\
\text { difficult/difficulty, not easy, constraint(s)/limits/limitations, } \\
\text { serious/seriousness, no choice(s), no option(s), sacrifices, no } \\
\text { Discourse of political reluctance } \\
\text { wish/unwillingness, inevitable, no room to maneuver, } \\
\text { incapacity, obligation(s), worse, hard, unpopular }\end{array}$ \\
\cline { 1 - 2 } Discourse of negative consequences & \\
\cline { 1 - 2 } Discourse of exceptional circumstances &
\end{tabular}

\begin{tabular}{l||l}
\hline \hline Relativization of intervention by Troika & Main terms and expressions \\
\hline \hline Discourse of national improvement & $\begin{array}{l}\text { bearing fruit, positive evaluation, recover, overcome, } \\
\text { successful, improve/improvement, progress, } \\
\text { prosper/prosperity, sovereignty/ sovereign, autonomy, } \\
\text { independence, credibility, reputation, responsibility, } \\
\text { responsiveness, the public interest, national interest, } \\
\text { determination, confidence, there are alternatives, room to } \\
\text { maneuver, control, choice(s), option(s), } \\
\text { appropriateness/appropriate, solution(s), } \\
\text { capacity/ability/capability, capable/able, fault, blame, } \\
\text { irresponsible/irresponsibility past, previous/previously, } \\
\text { precedent, former government(s), legacy, guilt/guilty, } \\
\text { inheritance }\end{array}$ \\
\hline Discourse of national choice & \\
\hline Discourse of national guilt &
\end{tabular}

Figure 1: Frequency of the strategies of depoliticization and relativization by

communicative arena

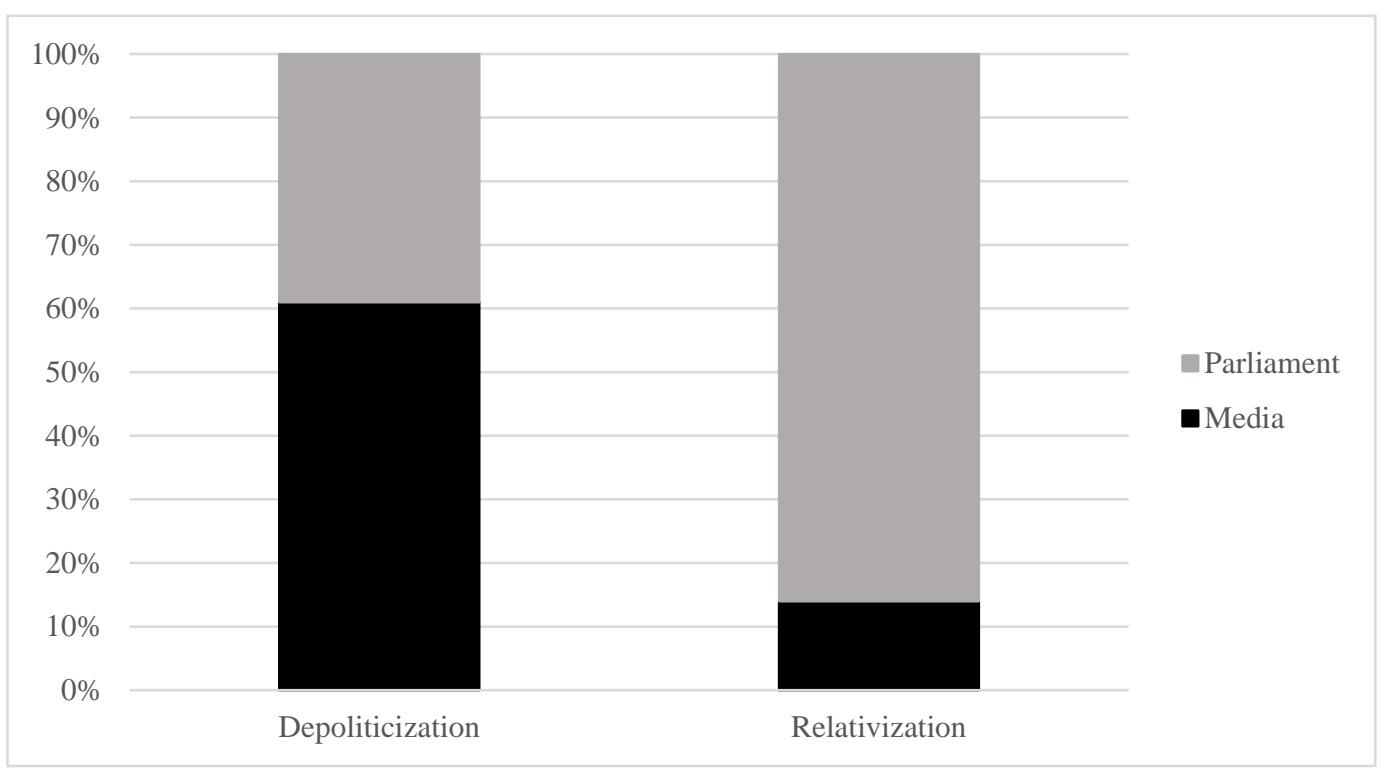

